\title{
Localized neuropathic pain
}

\author{
Ricardo Plancarte-Sánchez, * Marcela Samano-García, María del Rocío Guillén-Núñez and \\ Antonio Equihua-Ortega \\ Pain Clinic, Instituto Nacional de Cancerología, Mexico City, Mexico
}

\begin{abstract}
Localized neuropathic pain (LNP) is of peripheral origin and is characterized by circumscribed areas of pain with abnormal skin sensitivity or spontaneous symptoms that are characteristic of neuropathic pain, e.g., burning pain. It should be noted that LNP is confined to a specific area no larger than a letter size sheet of paper. LNP accounts for $60 \%$ of neuropathic pain syndromes. There is no single etiology of LNP. The diagnostic approach is similar to that for other neuropathic pain conditions. General diagnostic tools are used to assess clinical features. So far, there are no specific guidelines for the management of LNP; for this reason, guidelines for general neuropathic pain are used. Topical treatments are included as part of second-line strategies in the Canadian Pain Society guidelines. Despite the lack of guidelines, $5 \%$ lidocaine patches and $8 \%$ capsaicin patches have been proven effective in LNP models.
\end{abstract}

KEY WORDS: Localized neuropathic pain. Pain topical treatment. Lidocaine patch. Capsaicin patches.

\section{Dolor neuropático localizado}

\section{Resumen}

El dolor neuropático localizado (DNL) es de origen periférico y se caracteriza por áreas circunscritas de dolor con sensibilidad anormal de la piel o síntomas espontáneos característicos de dolor neuropático, por ejemplo, dolor urente. Se debe resaltar que el DNL está confinado a un área específica no mayor a una hoja de papel tamaño carta. El DNL representa $60 \%$ de las condiciones de dolor neuropático. No existe una única etiología. El abordaje diagnóstico es similar al de otros síndromes dolorosos neuropáticos. Se utilizan herramientas diagnósticas generales para evaluar las características clínicas. En la actualidad no existen guías específicas de manejo del DNL, por lo que se utilizan las guías para dolor neuropático en general. En las guías de la Sociedad Canadiense de Dolor se incluyen los tratamientos tópicos como parte de las estrategias de segunda línea. Pese a la falta de guías, los parches de lidocaína a $5 \%$ y los parches de capsaicina a $8 \%$ han demostrado ser efectivos en modelos de DNL.

PALABRAS CLAVE: Dolor neuropático localizado. Tratamiento tópico del dolor. Parche de lidocaína. Parches de capsaicina.

\section{Introduction}

Neuropathic pain is defined as pain that is secondary to a disease or lesion that affects the somatosensory system. ${ }^{1-3}$ This type of pain has several presentation forms: it can be continuous or recurrent episodic, and clinical features can refer to models of evoked or spontaneous pain. Neuropathic pain descriptors include burning, tingling, hyperalgesia, allodynia, electric shock sensation, pain to cold or heat, and numbness. ${ }^{1}$ Both
Correspondence:

*Ricardo Plancarte-Sánchez

E-mail: planky2b@yahoo.com.mx
Gac Med Mex. 2021;157:302-308

Contents available at PubMed

www.gacetamedicademexico.com

0016-3813/@ 2020 Academia Nacional de Medicina de México, A.C.. Published by Permanyer. This is an open access article under the CC BY-NC-ND license (http://creativecommons.org/licenses/by-nc-nd/4.0/). 
the expression of increased sensation to a stimulus that can cause pain (hyperalgesia) or pain response to an innocuous stimulus (allodynia) are objective descriptors that can accompany neuropathic pain. ${ }^{4}$

As for temporality, neuropathic pain can be acute or chronic; duration of the former is less than three months, and that of the latter, longer than that time. ${ }^{1}$

According to the level of nervous system compromise, neuropathic pain is divided into central neuropathic pain, when there is spinal or supra-spinal cord compromise, and peripheral, when involvement is prior to spinal cord relay. ${ }^{5,6}$

Localized neuropathic pain (LNP) is peripheral in origin and is characterized by circumscribed areas of pain with abnormal skin sensitivity or spontaneous symptoms, characteristic of neuropathic pain, e.g., burning pain. In addition, it should be noted that LNP is confined to a specific area not larger than a letter-size paper sheet. ${ }^{6,7}$

The prevalence of peripheral neuropathic pain is approximately $2 \%$ in the general population and $8 \%$ in patients older than 55 years of age. ${ }^{8}$ Diabetic neuropathy is the leading cause of neuropathic pain in the world. ${ }^{9,10}$ LNP accounts for $60 \%$ of neuropathic pain conditions. $^{6}$

The main causes of LNP are associated with the following conditions: $6,10,11$

- Infections (varicella zoster or human immunodeficiency virus).

- Metabolic diseases (diabetes mellitus, alcoholism, vitamin $B_{12}$ deficiency).

- Nutritional deficiency conditions.

- Toxic causes (ethanol, chemotherapy).

- Surgeries (thoracotomy or mastectomy, cesarean section, arthroscopy or arthroplasty, saphenectomy, inguinal surgery, cholecystectomy, among others).

- Nerve entrapments (Morton's neuroma, tarsal and carpal tunnel syndrome).

- Pathologies affecting nerve radicelae (radiculalgia sequelae, low back pain, neuralgia, cervicobrachial syndrome).

- Complex regional pain syndrome type 1.

Neuropathic pain qualitative characteristics lead to the assumption of this disorder; however, recent development of diagnostic questionnaires has helped detecting clinical components of neuropathic origin in a simple, quick and specific way. These screening tools are the DN4 questionnaire, painDETECT, the Neuropathic Pain Symptom Inventory (NPSI) and the LANSS scale. ${ }^{5}$ For LNP clinical diagnosis there is also a tool called the Diagnostic Tool. 4,6,13,14 In general, neuropathic pain diagnosis is established through medical history, physical examination, and confirmatory tests. ${ }^{14}$

As for the management of LNP, three stages have been proposed: 2,5

1. Screening and diagnosis

2. Treatment

\section{Follow-up model}

Once clinical diagnosis has been established, neuropathic pain treatment is aimed at reducing the symptoms and improving patient functionality (Fig. 1).,10,15

There are different publications where reference is made to the pharmacological algorithm for the patient with neuropathic pain (Table 1). ${ }^{16,17}$

It is important pointing out that if the patient presents with extreme hyperalgesia or uncontrollable symptoms despite appropriate treatment, referral to a specialist is recommended, regardless of the stage of treatment and care, for diagnostic reassessment. ${ }^{2}$

There are no specific guidelines or treatment recommendations for LNP, which is why those that exist for neuropathic pain in general are used. ${ }^{12}$

The European Federation of Neurological Societies and the International Association for the Study of Pain recommend the use of tricyclic antidepressants, anticonvulsants, and serotonin and norepinephrine reuptake inhibitors as the first option in the treatment of peripheral neuropathy; however, effectiveness occurs in approximately 30 to $40 \%$ of patients, which is related to the adverse effects of these drugs, which decrease the quality of life. $5,18,19,20$

The Canadian Pain Society guidelines refer that, for LNP, in addition to standard treatments, topical use of lidocaine is included as second-line treatment. ${ }^{17}$

It should be mentioned that non-steroidal anti-inflammatory drugs and paracetamol have not been shown useful in the treatment of neuropathic pain. ${ }^{5}$

The management of neuropathic pain is a clinical and therapeutic challenge, which sometimes does not show favorable results for months or even years. For this reason, different societies, including the Neuropathic Pain Special Interest Group (Neupsig, from the International Association for the Study of Pain), the European Pain Federation, and the Canadian Pain Society, have proposed stepwise treatments for the management of chronic neuropathic pain and their levels of evidence, which are described in Table 2. 2,5,12,19,20,21

In the particular case of LNP treatment, the use of topical agents is justified, unless there is any contraindication 


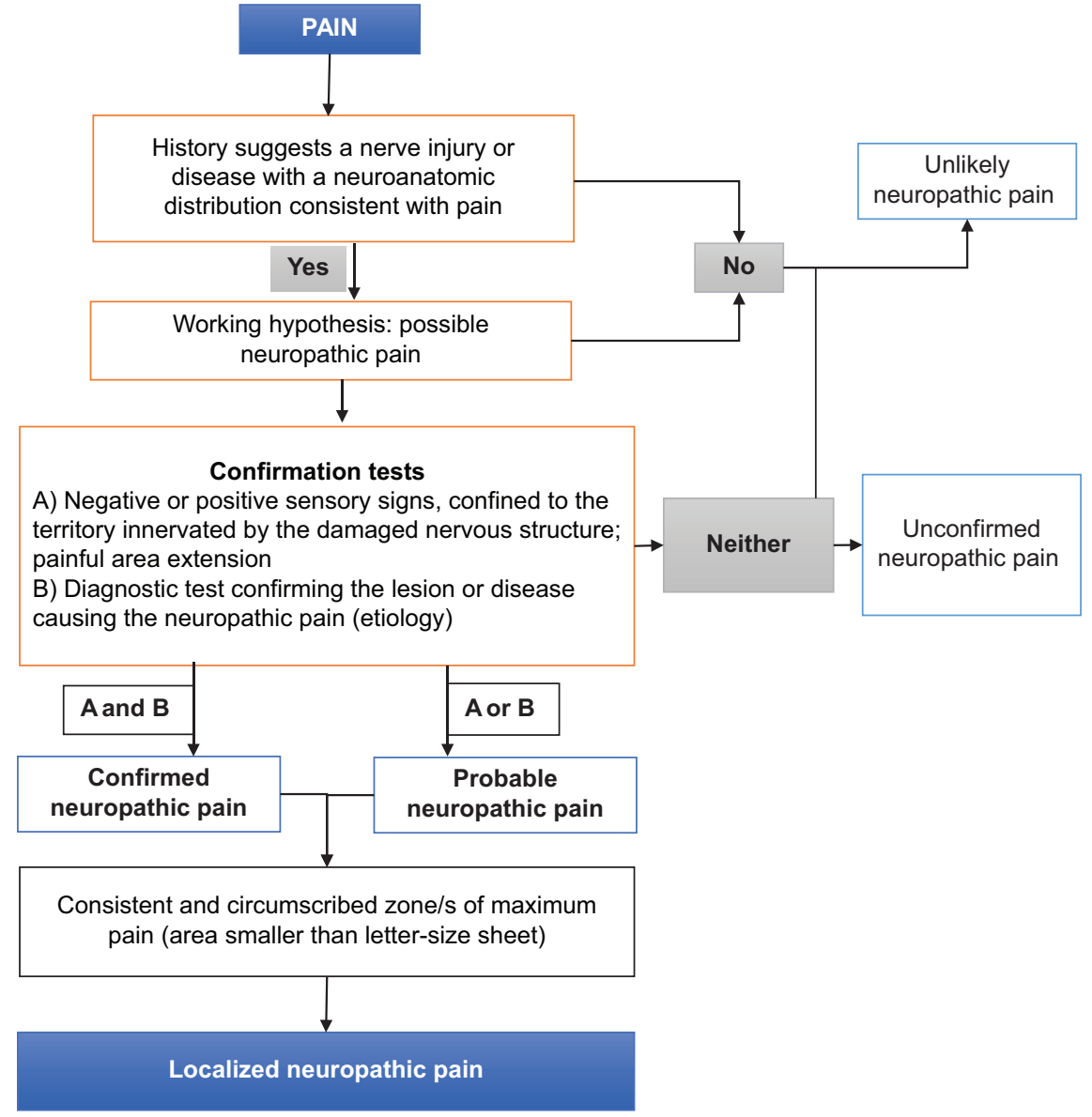

Figure 1. Localized neuropathic pain detection tool. Modified from Mick $G$ et al.: Is an easy and reliable diagnosis of localized neuropathic pain (LNP) possible in general practice? Development of a screening tool based on IASP criteria. ${ }^{10}$

Table 1. Neuropathic pain step by step pharmacological treatment

1. Evaluation and diagnosis establishment

- Establish and treat neuropathic pain cause

- Identify relevant comorbidities

- Explain the diagnosis, plan and treatment to the patient

2. Start symptom treatment with one or more of the following options:

- Selective serotonin and norepinephrine reuptake antidepressants

$-\alpha 2-\delta$ calcium channel ligands

- Lidocaine $5 \%$ patches

- Opioid analgesics or tramadol, in selected clinical circumstances

- Non-pharmacological treatments, after evaluation

3. Reassessment of pain and health-related quality of life

- If pain was substantially relieved and adverse side effects are tolerable, continue treatment

- If pain did partially improve, adjust initial dose of the drug or add another first-line agent

- If there is no adequate pain control, switch to other first-line drug

4. If first and second line pharmacological treatments fail, consider other first-line drugs or refer to pain specialist.

Source: Dworkin RH, O'Connor AB, Backonja M, Farrar JT, Finnerup NB, Jensen

TS, et al. Pharmacologic management of neuropathic pain: evidence-based

recommendations. ${ }^{16}$ such as lesion, atrophy or infection of the affected area of the body. ${ }^{16,30,31}$ This therapeutic model offers the following benefits: $2,15,31,32$

- It decreases LNP and prevents adverse effects that might occur with oral treatment. ${ }^{16}$

- Doses are lower than orally-administered drugs total doses. ${ }^{2}$

- The risk of overdose and drug interactions is much lower than with orally administered drugs. ${ }^{2}$

- It reduces polypharmacy, especially in older adults. ${ }^{2,32}$

In the treatment of LNP, anesthetics, muscle relaxants, anti-inflammatory drugs, antidepressants or a combination of these drugs have been used; however, some of them lack the level of evidence to support their use in this type of pain (Fig. 2). ${ }^{16,33}$

Topical agents that are used in the treatment of LNP include:

- Lidocaine $2.5 \%$ and prilocaine $2.5 \%$ emulsion, which is the most widely used topical anesthetic in the management of LNP. ${ }^{2}$ 
Plancarte-Sánchez R, et al.: Localized neuropathic pain

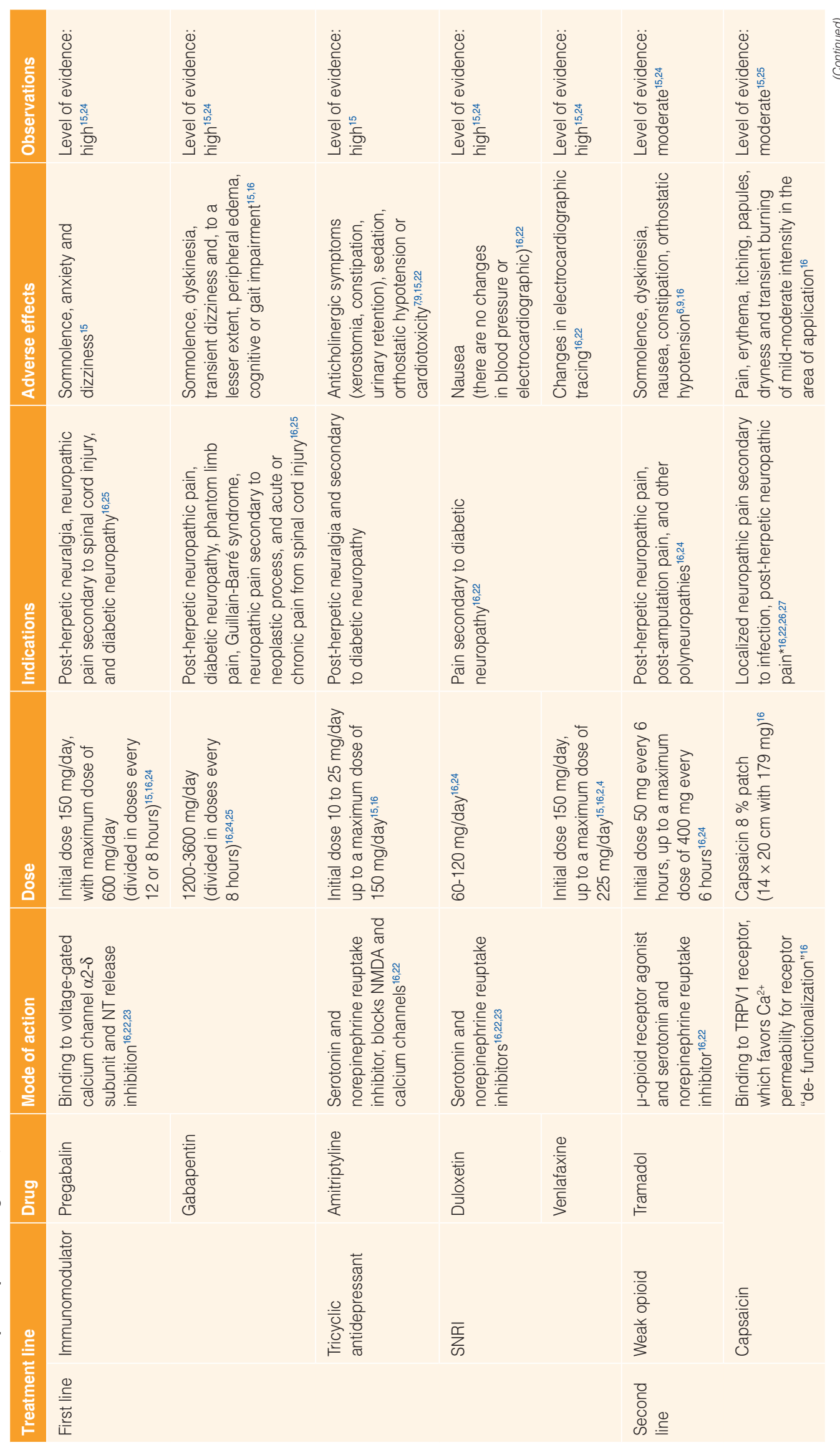




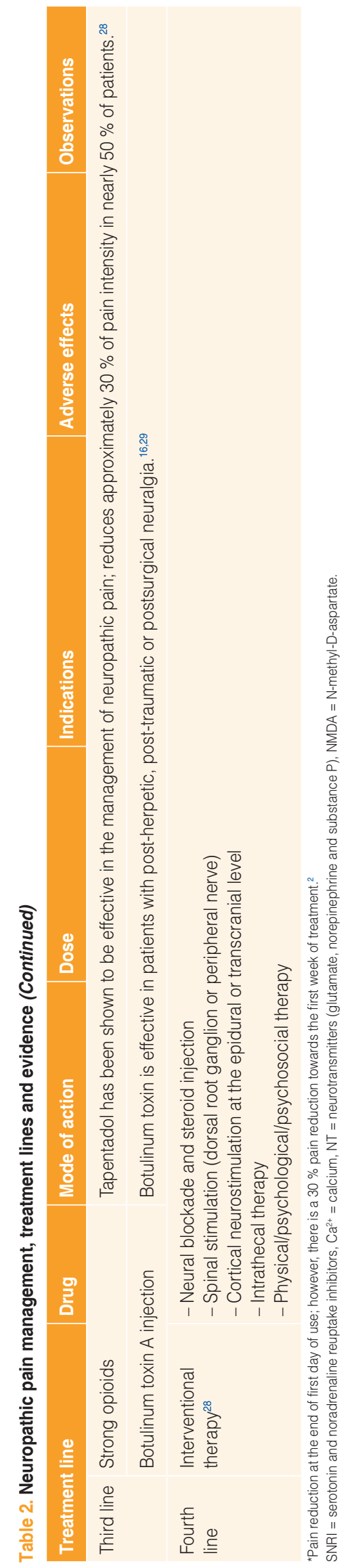

- lidocaine $5 \%$ patch (10 to $14 \mathrm{~cm}$ in size, with $700 \mathrm{mg}$ of lidocaine), a first-line topical drug that blocks sodium channels and stabilizes neuronal membranes (electrical threshold increase), thereby reducing ectopic discharges activity and improving pain transduction. .,8,34 $^{2}$ The recommended dose, depending on the affected anatomical area, is one to three patches for 12 hours, whereby results are obtained in between two and four weeks. ${ }^{6,35}$ Their use is indicated in the treatment of post-herpetic neuralgia (with high efficacy), diabetic polyneuropathy, carpal tunnel syndrome, myofascial pain syndrome, pain secondary to osteoarthritis and chronic postoperative pain. ${ }^{36,37}$

In several case reports of patients diagnosed with post-herpetic neuralgia, $60-70 \%$ reduction of the area of pain was observed after three months of treatment with lidocaine $5 \%$ patches. ${ }^{16,38}$

Numerous patients have reported the use of topical lidocaine $5 \%$ for more than eight years with no adverse effects. ${ }^{2}$ Its adverse effects, which globally occur in less than $3 \%$, include mild erythema, itching, edema, or skin irritation at the site of application. ${ }^{2}$

Other topical anesthetics with bupivacaine or mepivacaine have been tested in animals; a reduction in hyperalgesia has been observed in comparison with lidocaine, although they continue on research protocols. $^{16}$

Ketamine is a parenteral anesthetic that offers analgesia at suboptimal anesthetic doses; ${ }^{16}$ its mechanism of action involves a non-competitive blockade of NMDA (N-methyl-D-aspartate) receptors, which causes pain modulation by blocking glutamate synthesis. ${ }^{16}$ Application of ketamine $0.5-1 \%$ gel in patients with post-herpetic neuropathy, diabetic polyneuropathy and pain secondary to trauma has not demonstrated efficacy; however, in patients with complex regional pain syndrome, a reduction in hyperalgesia and allodynia was observed after the application of $10 \%$ ketamine..$^{16,38}$

Baclofen is a muscle relaxant, $\mathrm{GABA}_{\mathrm{B}}$ receptor agonist, which reduces nerve impulse at the afferent pathways level through cellular hyperpolarization (intracellular potassium ions increase and calcium ions decrease).$^{16}$ In human studies, topical baclofen $5 \%$ as monotherapy in the management of neuropathic pain related to acromegaly and its combined use in the treatment of neuropathic pain secondary to lumbar spine dural herniation-associated radiculopathy has shown efficacy in pain reduction, with a high level of evidence. ${ }^{16,38}$ 


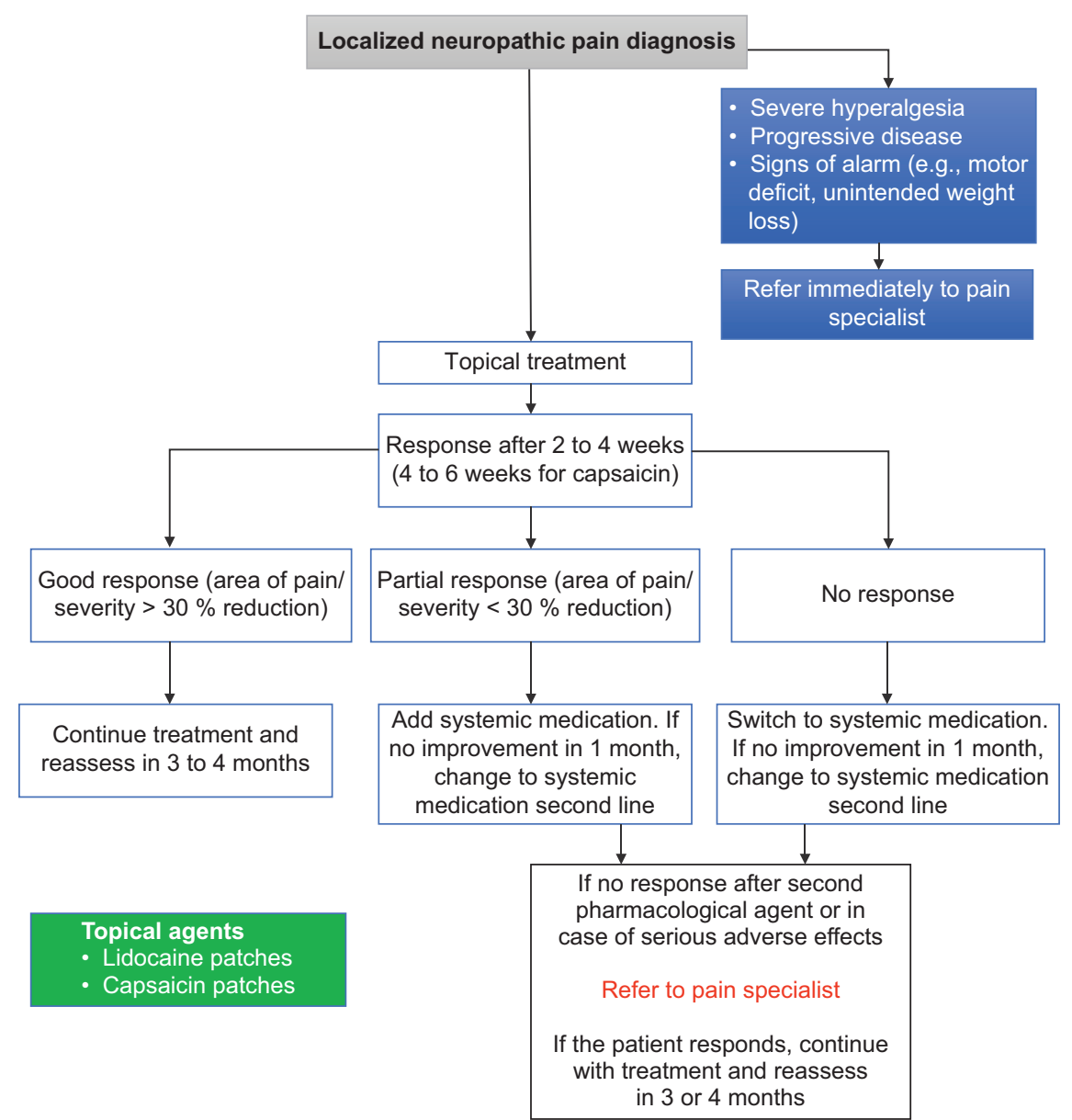

Figure 2. Algorithm for diagnosis and treatment of localized neuropathic pain. Based on Likar $R$ et al.: Treatment of localized neuropathic pain of different etiologies with the $5 \%$ lidocaine medicated plaster - a case series. ${ }^{33}$

As for topical non-steroidal anti-inflammatory drugs, diclofenac, which acts at the peripheral level, demonstrated good results in the treatment of orofacial neuropathic pain after topical administration of $5 \%$ diclofenac, with a moderate level of evidence; application is safe, without dermatological adverse effects. ${ }^{16,39}$ The use of topical salicylates (aspirin and diethyl ether) have been proven excellent in the management of post-herpetic neuralgia, with moderate level of evidence. ${ }^{16}$

Regarding topical tricyclic antidepressants, amitriptyline is a serotonin and norepinephrine reuptake inhibitor by blocking voltage-gated sodium, potassium and calcium channels, as well as muscarinic, cholinergic, nicotinic, histaminergic, alpha-2 adrenergic receptors and NMDA receptors. ${ }^{16,23,38}$ Results have been ambiguous with amitriptyline at concentrations of $1-5 \%$ in the treatment of post-herpetic pain and diabetic or post-traumatic neuropathy: in the management of pain due to idiopathic axonal polyneuropathy and post-traumatic neuropathy with amitriptyline at concentrations of 5-10
$\%$, a low level of evidence was obtained. ${ }^{16}$ Concentrations higher than $10 \%$ might turn out being effective in the management of pain; however, similar adverse effects to those systemically produced have been observed. ${ }^{13,16}$

Ambroxol is a mucolytic agent with anesthetic effects through the block of voltage-gated sodium channels, 40 times more potent than lidocaine. Although a reduction of allodynia has been observed in LNP when topically applied, the results are inconclusive..$^{16,39}$ In a report of cases, loperamide cream $5 \%$ was effective for the management of intractable neuropathic pain. ${ }^{39}$

\section{Conclusions}

Neuropathic pain syndromes are frequently observed in different clinical scenarios. LNP accounts for $60 \%$ of neuropathic pain conditions ${ }^{6}$ and, undoubtedly, affects the quality of life of those who suffer from it. ${ }^{5}$ 
For this reason, it is important for medical personnel to identify neuropathic pain different scenarios, including LNP syndromes, for which other pharmacological modalities, such as topical treatments, can be offered, mainly in elderly people who already receive multiple drugs. . $^{2,3,5,9}$

\section{Conflict of interests}

The authors declare that they have no conflicts of interest.

\section{Funding}

The present research did not receive any specific grant from agencies of the public, commercial or non-profit sectors.

\section{Ethical disclosures}

Protection of human and animal subjects. The authors declare that no experiments were performed on humans or animals for this research.

Confidentiality of data. The authors declare that no patient data appear in this article.

Right to privacy and informed consent. The authors declare that no patient data appear in this article.

\section{References}

1. Scholz J, Finnerup NB, Attal N, Aziz Q, Baron R, Bennett Ml, et al. The IASP classification of chronic pain for ICD-11: chronic neuropathic pain. Pain. 2019;160:53-59

2. Allegri M, Baron R, Hans G, Correa-Illanes G, Mayoral-Rojals V, Mick G, et al. A pharmacological treatment algorithm for localized neuropathic pain. Curr Med Res Opin. 2016;32:377-384

3. Mick G, Baron R, Finnerup NB, Hans G, Kern KU, Brett B, et al. What is localized neuropathic pain? A first proposal to characterize and define a widely used term. Pain Manag. 2012;2:71-77.

4. Finnerup NB, Haroutounian S, Kamerman P, Baron R, Bennett DLH Bouhassira D, et al. Neuropathic pain: an updated grading system for research and clinical practice. Pain. 2016;157:1599-1606.

5. Colloca L, Ludman T, Bouhassira D, Baron R, Dickenson AH, Freeman R, et al. Neuropathic pain. Nat Rev Dis Prim. 2017;3:1-20.

6. Pickering G, Martin E, Tiberghien F, Delorme C, Mick G. Localized neuropathic pain: an expert consensus on local treatments. Drug Des Devel Ther. 2017;11:2709-2718

7. Mayoral V, Pérez-Hernández C, Muro I, Leal A, Villoria J, Esquivias A. Diagnostic accuracy of an identification tool for localized neuropathic pain based on the IASP criteria. Curr Med Res Opin. 2018;34:1465-1473.

8. Kraychete DC, Sakata RK. Painful peripheral neuropathies. Rev Bras Anestesiol. 2011;61:649-658.

9. Eastman RC. Neuropathy in diabetes. En: Diabetes research and clinical practice. 1995;30:75.

10. Mick G, Baron R, Correa-Illanes G, Hans G, Mayoral V, Frías X, et al Is an easy and reliable diagnosis of localized neuropathic pain (LNP) possible in general practice? Development of a screening tool based on IASP criteria. Curr Med Res Opin. 2014;30:1357-1366.

11. Golan-Vered Y, Pud D. Chemotherapy-induced neuropathic pain and its relation to cluster symptoms in breast cancer patients treated with paclitaxel. Pain Pract. 2013:13:46-52.

12. Casale R, Mattia C. Building a diagnostic algorithm on localized neuropathic pain (LNP) and targeted topical treatment: Focus on $5 \%$ lidocaine-medicated plaster. Ther Clin Risk Manag. 2014;10:259-268.
13. Hatch MN, Cushing TR, Carlson GD, Chang EY. Neuropathic pain and $\mathrm{SCl}$ : Identification and treatment strategies in the $21^{\text {st }}$ century. J Neurol Sci. 2018;384:75-83

14. Treede RD, Jensen TS, Campbell JN, Cruccu G, Dostrovsky JO, Griffin JW, et al. Neuropathic pain: redefinition and a grading system for clinical and research purposes. Neurology. 2008;70:1630-1635.

15. Guy SD, Mehta S, Casalino A, Côté I, Kras-Dupuis A, Moulin DE, et al. The CanPain $\mathrm{SCl}$ clinical practice guidelines for rehabilitation management of neuropathic pain after spinal cord: recommendations for treatment. Spinal Cord. 2016;54:S14-S23.

16. Dworkin RH, O'Connor AB, Backonja M et al. Pharmacologic management of neuropathic pain: evidence-based recommendations. Pain. 2007; 132:237-251

17. Moulin DE, Boul, er A, et al. Pharmacological management of chronic neuropathic pain - Revised consensus statement from the Canadian pain society. Pain Res Manag. 2014;19(6):e87.

18. Sommer C, Cruccu G. Topical Treatment of Peripheral Neuropathic Pain: Applying the Evidence. J Pain Symptom Manage. 2017;53(3):614-629. DOI:10.1016/j.jpainsymman.2016.09.015

19. Bistre S, Acevedo JC, Amaya A, et al. Guidelines for the diagnosis and management of neuropathic pain: Consensus of a group of latin american experts. J Pain Palliat Care Pharmacother. 2009;23(3):261-281. DOI:10.1080/15360280903098572

20. Cruccu G, Truini A. A review of Neuropathic Pain: From Guidelines to Clinical Practice. Pain Ther. 2017;6(S1):35-42. DOI:10.1007/s40122017-0087-0

21. Haanpää M, Attal N, Backonja M, et al. NeuPSIG guidelines on neuropathic pain assessment. Pain. 2011;152(1):14-27. DOl:10.1016/j. pain.2010.07.031

22. Dworkin RH, O'Connor AB, Audette J, et al. Recommendations for the pharmacological management of neuropathic pain: An overview and literature update. Mayo Clin Proc. 2010;85(3):S3-S14. DOI:10.4065/ mcp.2009.0649

23. Kremer M, Salvat E, Muller A, Yalcin I, Barrot M. Antidepressants and gabapentinoids in neuropathic pain: Mechanistic insights. Neuroscience. 2016:338:183-206. DOI:10.1016/j.neuroscience.2016.06.057

24. Attal N, Cruccu G, Haanpää M, et al. EFNS guidelines on pharmacological treatment of neuropathic pain. Eur J Neurol. 2006;13(11):11531169. DOI:10.1111/j.1468-1331.2006.01511.x

25. Attal N, Cruccu G, Baron R, et al. EFNS guidelines on the pharmacological treatment of neuropathic pain: 2010 revision. Eur J Neurol. 2010;17(9):1113-1123. DOI:10.1111/j.1468-1331.2010.02999.x

26. Treede RD, Wagner T, Kern KU, Arendt G, Birklein F, Cegla T, et al. Mechanism- and experience-based strategies to optimize treatment response to the capsaicin $8 \%$ cutaneous patch in patients with localized neuropathic pain. Curr Med Res Opin. 2013;29:527-538.

27. Pinto JT, Pereira FC, Loureiro MC, Gama R, Fernandes HL. Efficacy analysis of capsaicin $8 \%$ patch in neuropathic peripheral pain treatment. Pharmacology. 2018:101:290-297.

28. Casale R, Symeonidou Z, Bartolo M. Topical treatments for localized neuropathic pain. Curr Pain Headache Rep. 2017;21:15.

29. Park JH, Park HJ. Botulinum toxin for the treatment of neuropathic pain. Toxins (Basel). 2017:9:260

30. Kopsky DJ. Extending the therapeutic scope for the treatment of neuropathic pain with topical analgesics. J Pain Reli. 2016;5:3-5.

31. Peppin JF, Albrecht PJ, Argoff C, Gustorff B, Pappagallo M, Rice FL, et al. Skin matters: a review of topical treatments for chronic pain. part one: skin physiology and delivery systems. Pain Ther. 2015;4:17-32.

32. Pickering G, Lucchini C. Topical treatment of localized neuropathic pain in the elderly. Drugs Aging. 2020;37:83-89.

33. Lara-Solares A, Mayoral-Rojals V, Guillén-Núñez MR, Villafaña-Tello JJS, Cabtú-Brito C, Genis-Rondero MA, et al. Consenso multidisciplinario de diagnóstico y tratamiento del dolor neuropático periférico y localizado en México. Gac Med Mex. 2019:155:423-427.

34. Likar R, Demschar S, Kager I, Neuwersch S, Pipam W, Sittl R. Treatment of localized neuropathic pain of different etiologies with the $5 \%$ lidocaine medicated plaster - a case series. Int J Gen Med. 2014:8:9-14.

35. Buksnys T, Armstrong N, Worthy G, Sabatschus I, Boesl I, Swift SL, et al. Systematic review and network meta-analysis of the efficacy and safety of lidocaine $700 \mathrm{mg}$ medicated plaster vs. pregabalin. Curr Med Res Opin. 2020;36:101-115

36. Schreiber AK, Nones CFM, Reis RC, Chichorro JG, Cunha JM. Diabetic neuropathic pain: physiopathology and treatment. World $\mathrm{J}$ Diabetes. 2015:6:432

37. Palladini M, BoesI I, Koenig S, Buchheister B, Attal N. Lidocaine medicated plaster, an additional potential treatment option for localized post-surgical neuropathic pain: efficacy and safety results of a randomized, placebo-controlled trial. Curr Med Res Opin. 2019;35:757-766.

38. Knezevic NN, Tverdohleb T, Nikibin F, Knezevic I, Candido KD. Management of chronic neuropathic pain with single and compounded topical analgesics. Pain Manag. 2017;7:537-558.

39. Coderre TJ. Topical drug therapeutics for neuropathic pain. Expert Opin Pharmacother. 2018:19:1211-1220. 